HAJNÁ, Milena. ŠATY CHODICÍ. Každodennost a symbolika ve šlechtickém šatníku raného novověku. České Budějovice: Národní památkový ústav. 2016, 255 s. ISBN 9788087890172.

\title{
DOI: https://doi.org/10.31577/histcaso.2019.67.4.9
}

Autorka publikácie Milena Hajná vyštudovala Kultúrnu históriu na Jihočeské univerzitě v Českých Budějoviciach. Absolvovala vedecké zahraničné stáže vo Viedni a v Alcalá de Henares v Španielsku a zaoberá sa výskumom česko-španielskych vzt’ahov v ranom novoveku a každodennou kultúrou šl’achtických sídiel. Zameriava sa na dejiny odievania a kultúru cestovania, čoho výsledkom sú viaceré publikácie na túto tému. Jej kniha Šaty chodici prináša nový pohl'ad na odev v histórii. Je to nielen opis jednotlivých súčastí šatníka novovekého šl'achtica, ale najmä súvislosti zo života, ktoré s odevom súviseli. Zameriava sa na ranonovoveké „české země“ zasadené do širšieho stredoeurópskeho kontextu. Ked’že šaty a odev sú silne vizuálnym elementom, kniha je doslova prešpikovaná dobovými portrétmi najmä rodov z Rožmberka, Hradce, zo Švamberka, rodu Zrínskych zo Serynu, Eggenbergov, Schwarzenbergov, Černínov a mnohých d’alších. Okrem vizuálnych uvádza autorka aj množstvo archívnych prameňov. Nechýbajú odevné inventáre, súpisy majetku, účtovné záznamy, korešpondencia a aj denníky.

Kniha je rozdelená do dvoch hlavných kapitol. Prvá s názvom Šlechtic a jeho garderoba uvádza čitatel'a do odevnej problematiky a základnej terminológie. Vysvetl'uje hodnotu šiat a textílií, ktoré mali v minulosti omnoho väčšiu cenu ako dnes. Približuje spôsoby uskladňovania odevov, ich premiestňovania a starostlivost' o ne na konkrétnych príkladoch zo života šl'achty. Upresňuje význam slova garderóba a uvádza aj povolania, ktoré súviseli s jej udržiavaním. Výpisy s inventárov nám poskytujú približnú predstavu, kol'ko šatstva mal novoveký šl'achtic a čo konkrétne v garderóbe nesmelo chýbat'. Autorka uvádza dokonca aj súdne spory, ktoré boli vedené kvôli šatstvu, najmä v dedičských konaniach. Čitatel' si tak môže utvorit’ predstavu o nákladnosti a cene odevov $\mathrm{v}$ ranom novoveku. Na konci prvej kapitoly približuje autorka módne trendy, ktoré vtedy vládli v Európe a ktoré priamo či nepriamo ovplyvňovali šlachtickú módu v českých zemiach.

Druhá, omnoho rozsiahlejšia kapitola s názvom Oděv a životní cyklus šlechtice, sa zameriava na odev v živote šlachtica. Prvá podkapitola s názvom Stupně lidského života predstavuje odev v rôznych fázach života človeka: od narodenia až po smrt'. Autorka vel'mi originálne predstavuje odev na type dobovej rytiny označovanej ako stupne l'udského života, ktoré ikonograficky nadväzujú na stredoveké kolesá života alebo kolesá št'astia. Táto kapitola je v podstate opisom konkrétnych rytín, ktoré si autorka vybrala ako príklad. Opis miestami dopíňa aj o vysvetlenie určitých ikonografických detailov, no tiež sa odkláňa od hlavnej témy, čo pôsobí na čitatel’a trochu mätúco. Napriek tomu sú to vel'mi zaujímavé informácie, hoci sa vzd'al'ujú od danej problematiky. Za touto podkapitolou nasledujú jednotlivé fázy života človeka. Druhá podkapitola sa prirodzene venuje obdobiu detstva. Sú nám predstavené všetky textílie, ktoré sprevádzajú matku a diet’a už od pôrodu. Detské košiel'ky, plienky, ale aj honosnejšie košiel'ky na krst boli predmetom vel'kých príprav už počas tehotenstva. Látky a textil totiž neboli tak l'ahko dostupné ako v dnešných dobách, a preto tvorili aj značnú čast' výbavy nevesty. Text je obohatený aj 
o výklad ikonografie na detských šlachtických portrétoch, čo pomáha čitatel'ovi pochopit’ širšie dobové súvislosti. Vysvetl'uje, prečo šl'achtici obliekali svoje deti do náročných šiat, ktoré boli identické s odevom dospelých a taktiež, prečo bola krása ich detí tak vel'mi podstatná. Tretia podkapitola s názvom Mládenec a panna približuje obdobie dospievania a prípravy na budúcu spoločenskú kariéru a manželský život. Uvádza rozdiely v odievaní slobodnej ženy a vydatej, a život mládencov na tzv. gavalierskych cestách. Tu autorka trochu odbáča od témy a približuje módne trendy v zahraničí, napr. v Taliansku alebo Francúzsku. Uvádza denníky a trachtenbuchy, ktoré v tej dobe vznikali, taktiež literatúru, ktorá viedla mládencov na potulkách po svete. Spomína odevné zvyky na král'ovských dvoroch a konzekvencie vyplývajúce z ich nedodržiavania. K téme sa opät' vracia $\mathrm{v}$ stati o odeve mladých panien čakajúcich na vydaj. Ich život bol v porovnaní s mladými mužmi omnoho chudobnejší a spočíval v cibrení vlastností potrebných pre manželstvo. Štvrtá podkapitola s názvom Snoubenci, ženich a nevěsta mapuje jeden z najdôležitejších životných okamihov dvoch mladých l'udí. Textil a odev, teda najmä jeho dostatok a bohatstvo, bol pre zasnúbenie a svadbu tak dôležitý, že pokial' neboli zabezpečené šaty pre snúbencov, svadba sa nemohla konat'. Stat' sprevádza čitatel'a prípravami na svadbu nielen z pohl'adu ženícha a nevesty, ale aj svadobných hostí. Mnoho pozvaných šl'achticov muselo pozvanie na svadbu zrušit', pretože nemali adekvátny odev. Text vysvetl'uje bohatú symboliku zásnubných darov, ktoré si snúbenci posielali na znak svojej lásky, ale aj výpočet svadobných darov, v ktorých mal textil a odevy pevné miesto. Autorka používa množstvo zásnubných alebo priamo svadobných portrétov českej šl'achty, na základe ktorých si vie čitatel' urobit' vel'mi dobrú predstavu o odeve. Niektoré detaily odevu síce interpretuje nesprávne, no neuberá to textu na zaujímavosti. Spomína aj osud svadobných šiat po skončení veselia. Niektoré boli rozobraté a prešité, iné skončili ako dar niektorému z kostolov, alebo si ich manželia nechávali na pamiatku. Za touto podkapitolou nasleduje čast's názvom Manžel a manželka. Pre ženu to znamenalo nosit' čepiec ako symbol svojho statusu. Okrem toho sa jej odev zmenil aj v iných detailoch. Dekolt už nemohol byt' taký hlboký, farby a látky tak pestré. Mnohé manželské portréty tvorené ako pandanty nám ponúkajú náhl'ad do manželského života a jeho symboliky. Pes ako symbol vernosti, široká symbolika kvetov a farieb, drobné detaily na obrazoch rozprávajú príbehy skryté laickému pozorovatel'ovi. Smrt' patrí k životu, a tak sa d'alšia podkapitola venuje obdobiu života po odchode milovanej polovičky na večnost'. Vdovec a vdova obliekajú smútočný šat, ktorý jasne prezrádza okoliu ich spoločenský status. Čierna a biela ovládli garderóbu ovdovelého šl'achtica či šl’achtičnej. Smrt' panovníka alebo niekoho blízkeho z panovníckej rodiny znamenala pre dvoranov zaobstaranie si smútočného odevu a ten museli nosit' tak dlho, ako im to dvorské predpisy kázali. Pre šl'achticov to častokrát znamenalo vel'ké výdaje, ked’že nemohli niekol'ko mesiacov chodit' v jedných šatách. Pohřebni šaty je názov siedmej podkapitoly a mapuje, čo si novoveký šl'achtic vzal so sebou do truhly. Jeho prianie ohl'adne odevu bolo čast'ou poslednej vôle. Vel'mi často si šl'achtici na znak svojej pobožnosti priali byt' pochovaní v mníšskom habite. K smrti sa spája mnoho povier, ktoré autorka spomína a vysvetl'uje, vel'a z nich sa priamo dotýka odevu a iných textílií spojených s nebožtíkom. Katafalkové portréty, ktoré autorka pripojila k textu, nám prinášajú dokonalý pohl'ad na zvyky spojené so smrt'ou. Odev, ale aj doplnky, ako napríklad krucifixy, pátričky a medailóny so 
svätými sú jasne vykreslené a dajú sa dokonca identifikovat' podl'a opisu v dobových inventároch šl'achtica. Čast' tejto podkapitoly je venovaná aj pohrebným odevom detí. Posledná čast' nesie názov Šaty a šperky jako dar. Samotný názov podkapitoly nám vel’a prezradí o jej obsahu. Autorka uvádza, akú vel'kú hodnotu mali textílie a odevy, a prečo boli tak často vol'bou pre dar. Boli nimi obdarovávané všetky vrstvy vtedajšej spoločnosti: od král'ov až po poddaných. Textilom sa nemrhalo, bol spotrebovaný do poslednej nitky, čo je obrovský rozdiel oproti dnešným trendom.

Kniha Šaty chodici je krásna farebná publikácia plná zaujímavostí a nových pohl'adov na odevnú kultúru. Autorka samotný text doplnila rozsiahlym poznámkovým aparátom, ktorý síce obsahuje mnoho užitočných informácií, no častokrát na úkor hlavného textu a odvádza čitatel'ovu pozornost'. V texte sa nachádza mnoho odborných či cudzích výrazov, ktoré sú uvedené kurzívou, ale bez d’alšieho vysvetlenia. Čo knihe skutočne chýba je terminologický slovník, ktorý by pomohol čitatel'ovi laikovi lepšie pochopit' text. Takto je kniha skutočne obohacujúca len pre človeka zdatného v historickej odevnej terminológii. Pre bádatel'a v oblasti dobovej módy je to dokonalý odrazový mostík pre d'alší výskum, no bežný človek by potreboval doplnit' svoje vedomosti z iného zdroja, aby si mohol túto publikáciu skutočne vychutnat'.

Lenka Pajer

Historický ústav SAV

(interná doktorandka)

DUDEKOVÁ, Gabriela - MANNOVÁ, Elena. VOJAK MEDZI CIVILMI, CIVIL MEDZI VOJAKMI. Vzt’ah armády a spoločnosti v obdobi modernizácie. Bratislava, ProHistoria 2017, 512 s. ISBN 9788089910014.

DOI: https://doi.org/10.31577/histcaso.2019.67.4.10

Nezainteresovaný čitatel' by mohol nedocenit’ informáciu z titulného listu, že recenzovaná kolektívna monografia je dedikovaná kolegovi Vojtechovi Danglovi, preto začnem práve ňou. A ním. S vedomím rizika, na ktoré správne upozorňuje Ivan Kamenec už v úvode - že akákol’vek zmienka o kolegovi Danglovi hrozí okamžitým žánrovým skĺznutím zo štandardného akademického písania do laudatia. Nepomôžem si. Ide o problém zdiel'aný naprieč generáciami a nezávislý od špecifickej výskumnej orientácie. V tomto prípade má totiž konkrétna dedikácia na recenzované dielo aj výrazný formatívny vplyv. Vojtech Dangl nielen sám výborne píše o zaujímavých veciach, ale inšpiruje k tomu aj d’alších autorov, kolegov, kamarátov. Len do tejto publikácie, so striktným tematickým i chronologickým vymedzením, ich prispelo vyše dvadsat'. Výslednej konzistentnosti a čítavosti textu výrazne prospela i skvelá editorská práca hlavných autoriek Eleny Mannovej a Gabriely Dudekovej.

Prvé tri časti knihy sú venované vybraným témam z obdobia sklonku Habsburskej monarchie, prvej svetovej vojny a medzivojnového Československa, spojivom štvrtej je fenomén historickej pamäti. V závere publikácie hlavné autorky pripravili jej pät'strano- 